\title{
Additive effects of EGF and IL-1 $\beta$ regulate tumor cell migration and invasion in gastric adenocarcinoma via activation of ERK1/2
}

\author{
JUNYONG HAN $^{1 *}$, YANCHUAN XIE $^{1 *}$, FENGHUA LAN $^{1}$, YINGHAO YU $^{2}$, WEI LIU ${ }^{2}$, \\ JINHUA CHEN $^{4}$, FENG ZHENG ${ }^{6}$, XUENONG OUYANG ${ }^{7}$, XIANGQUAN LIN ${ }^{1}$, \\ YANHONG LIN ${ }^{1}$, QIAOJIA HUANG ${ }^{1}$, LIE WANG $^{3}$ and JIANMING TAN ${ }^{1,5}$ \\ Departments of ${ }^{1}$ Experimental Medicine, ${ }^{2}$ Pathology, ${ }^{3}$ General Surgery, ${ }^{4}$ Medical Statistics, \\ ${ }^{5}$ Organ Transplant Institute, ${ }^{6}$ Nephrology and Central Laboratory and ${ }^{7}$ Oncology, \\ Fuzhou General Hospital (Dongfang Hospital), Fuzhou, Fujian 350025, P.R. China
}

Received January 23, 2014; Accepted March 28, 2014

DOI: 10.3892/ijo.2014.2401

\begin{abstract}
Growth and inflammatory factors are associated with poor prognosis in gastric adenocarcinoma (GA); however, the additive effects of growth and inflammatory factors in GA remain unclear. In this study, we investigated the ability of epidermal growth factor (EGF) and interleukin (IL-1 $\beta$ ) to activate extracellular signal-regulated kinase (ERK)1/2 in GA cells, and correlated the relationships between their roles with the metastatic potential both in GA cells and GA tissues. The effects of EGF, IL-1 $\beta$ and EGF plus IL-1 $\beta$ in AGS and MKN-45 GA cells were examined using western blotting, Transwell migration and invasion assays, immunocytochemical staining and an activator protein (AP)-1 luciferase reporter gene assay, and was further characterized in GA tissues by immunohistochemistry. The results exhibited that EGF and IL-1 $\beta$ additively activated ERK1/2, increased migration and invasion than either EGF or IL-1 $\beta$ alone in AGS and MKN-45 cells. The mechanisms were involved in upregulating MMP-9 expression through increasing AP-1 transcriptional activity via ERK1/2 pathway; these effects were dose-dependently inhibited by silencing ERK1/2 or using U0126. In vivo data also confirmed that the overexpression of p-ERK1/2 in GA tissues correlated well with the EGF, IL-1 $\beta$, EGF plus IL-1 $\beta$, and was associated with metastasis, which was well correlation with the expres-
\end{abstract}

Correspondence to: Professor Qiaojia Huang, Department of Experimental Medicine or Dr Lie Wang, Department of General Surgery, Fuzhou General Hospital (Dongfang Hospital), 156 North Xi-er Huan Road, Fuzhou, Fujian 350025, P.R. China

E-mail: huangqj100@126.com fzptwk@xmu.edu.cn

*Contributed equally

Key words: epidermal growth factor and interleukin-1 $\beta$, additive effect, extracellular signal-regulated kinase1/2, gastric adenocarcinoma, metastasis sion of MMP-9 and c-fos (AP-1). The results demonstrate that growth and inflammatory factors play an important role in metastasis of GA by additively activating ERK-1/2 and AP-1, and upregulating MMP-9. As both cytokines contribute to the migration and invasion of GA cells, EGF/IL-1 $\beta /$ ERK1/2 pathways may be key pathways closely associated with GA progression.

\section{Introduction}

Gastric cancer is one of the most common malignancies worldwide (1). The 5-year survival rates for gastric cancer remain poor throughout the world $(1,2)$, especially in patients with advanced disease or metastasis, as gastric cancer is highly aggressive and resistant to anticancer drugs. Though the molecular mechanisms regulating the development of gastric cancer are not yet fully elucidated, increased cell migration and invasion are closely related to carcinogenesis and poor prognosis in gastric cancer (3). Therefore, understanding the mechanisms which regulate these biological changes in gastric cancer cells may help to reduce the incidence of gastric cancer and lead to the identification of novel methods to protect against or treat gastric cancer.

Activation of extracellular signal-regulated kinase (ERK), a major member of the mitogen-activated protein kinase (MAPK) superfamily, can increase migration and invasion in many cancer cells $(4,5)$. Six mammalian ERK homologs have been identified to date, termed ERK1, ERK2, ERK3, ERK5, ERK7 and ERK8 (6,7). It is well established that MAP3K kinases can activate MAP2K kinases, which in turn can activate MAPKs. Multiple MAP3Ks and MAP2Ks have been verified to activate the ERK signaling pathway; including MAP3Ks such as Raf and MEKK3, and MAP2Ks such as MAPK/ERK kinase 1 (MEK1) and MEK2. ERK1/2 is a direct substrate of MEK1 and MEK2 (8). ERK1 and ERK2 are two of the most essential regulators of cell growth, proliferation, differentiation, migration and invasion $(9,10)$. Activation of ERK1/2 is observed in many human cancers and is closely related to cancer cell progression and poor prognosis. Therefore, the ERK1/2 signaling pathways 
are regarded as potentially useful targets for the treatment of cancer (11).

A variety of growth factors including epidermal growth factor (EGF) can activate ERK1/2 and lead to increased cell growth, differentiation, migration and survival. Although it is well known that the EGF/Raf/MEK1/2/ERK1/2 pathway is closely associated with cancer cell metastasis, and activation of ERK1/2 is capable of promoting the growth of gastric cancer cells (12), the effect of ERK1/2 signaling on the metastasis of gastric adenocarcinoma cancer (GA) cells remains to be determined.

Inflammation induced by cytokines plays important roles in cancer carcinogenesis and progression, especially in gastric cancer. A lot of studies have demonstrated that gastric cancer may be an 'inflammatory disease', due to induction by Helicobacter pylori (HP) infection. One of the most important characterizations of HP infection is elevated interleukin (IL)-1 $\beta$ level in location gastric tissue, which may cause inflammation-associated gastric carcinogenesis. However, the underlying molecular mechanism by which the IL- $\beta$ signaling is regulated during gastric cancer carcinogenesis is still not understood. Accumulating evidence demonstrates that the tumor microenvironment exerts a variety of pleiotropic effects during malignant processes, and plays an important role in carcinogenesis, malignant transformation and tumor growth, metastasis and survival $(13,14)$. Cytokines induced by inflammation or secreted by tumor cells make up the important ingredients of the tumor microenvironment. Previous findings demonstrate that IL- $1 \beta$ is capable of activating ERK $1 / 2$ and the transcription factor activator protein (AP)-1 in several cell types, which is believed to promote inflammation-associated carcinogenesis and plays a crucial role in cancer metastasis $(15,16)$. However, it is not unclear whether IL-1 $\beta$ can activate ERK1/2 and regulate ERK1/2-mediated metastasis in GA. Moreover, little is known about the additive effects of EGF and IL-1 $\beta$ on the metastasis of GA.

In this study, we determined the additive ability of EGF and IL- $1 \beta$ to activate ERK1/2 in GA cells, and characterized the molecular mechanisms regulating additive effects of EGF plus IL-1 $\beta$-induced ERK1/2-mediated metastasis in GA cells; furthermore, we investigated the relationship between the expression of EGF plus IL-1 $\beta$, and the activation of ERK1/2 and the clinicopathological features in GA tissues.

\section{Materials and methods}

Cell culture and transfection with siRNA. AGS and MKN-45 cells (American Type Culture Collection, Manassas, VA and Japanese Cancer Research Bank, respectively) were grown in F12 and DMEM medium, respectively (Invitrogen, Carlsbad, $\mathrm{CA}$, USA) containing $10 \%$ fetal bovine serum (FBS) at $37^{\circ} \mathrm{C}$ in an incubator containing $5 \% \mathrm{CO}_{2}$. siRNA against ERK1/2 (Cell Signaling Co., Danvers, MA, USA) (50-200 nM) was transfected into cells with Lipofectamine 2000 according to the manufacturer's instructions.

Western blot analysis for ERK1/2. The western blotting for the expression of ERK1/2 and p-ERK1/2 in AGS and MKN-45 cells used the methods described by us previously $(17,18)$. The rabbit anti-human ERK1/2 or p-ERK1/2 antibody was 1:1000 or 500 diluted (Cell Signaling Co.). Anti- $\beta$-actin (1:6000 dilution, Sigma, St. Louis, MO, USA) was used as a control for the western blots.

Cell migration and invasion assay. For AGS and MKN-45 cell invasion assays, we used methods described by Sumida et al (19). Millicell Hanging Cell Invasion Chambers with 8- $\mu \mathrm{m}$ pore filter (Millipore Corp., Billerica, MA) were coated with $12 \mu \mathrm{l}$ of ice-cold Matrigel (Becton-Dickinson Labware, Bedfore, MA). AGS or MKN-45 cells ( $5 \times 10^{4} /$ well) were added to the upper chamber of these Matrigel chambers in $200 \mu 1$ serum-free F12 or DMEM medium with $50 \mathrm{ng} / \mathrm{ml}$ human epidermal growth factor (EGF) or $20 \mathrm{ng} / \mathrm{ml} \mathrm{IL-1} \beta$ or both (R\&D Systems, Minneapolis, MN) or not, which were then put into 24-well plates in F12 or DMEM medium containing $10 \%$ FBS. To evaluate the role of inhibitor U0126, cells were pre-treated with the reagent for $3 \mathrm{~h}$, and then performed the stimulations. To evaluate the role of ERK1/2 siRNA in cell migration and invasion, AGS and MKN-45 cells were transfected with scramble siRNA or ERK1/2 siRNA for $36 \mathrm{~h}$, and followed the transfection, the cells were seeded at a density of $5 \times 10^{4} /$ well and then in $200 \mu \mathrm{l}$ of serum-free medium for the stimulation as mentioned above. Following a $20-\mathrm{h}$ incubation, cells were fixed with methanol and were then stained with crystal violet or Giemsa. Cotton tips were used to remove the cells that remained in the Matrigel or attached to the upper side of the filter. Light microscopy was used to count the cells on the lower side of the filter. The assays were performed in duplicate, and the results were averaged. The methods used for migration assay was almost the same as invasion assay mentioned above except no Matrigel was used for coating the well and the time of incubation was $15 \mathrm{~h}$.

Confocal microscopy assay. The relationship between the expression of p-ERK1/2, and MMP-9 in response to EGF, or IL-1 $\beta$ or both in AGS and MKN-45 cells were detected by confocal microscopy using methods described by us previously with anti-p-ERK1/2 (Cell Signaling Co.) and anti-MMP-9 antibodies (Abcam Co., Cambridge, MA, USA) (18).

AP-1 luciferase reporter gene assay. AGS and MKN-45 cells were transfected with AP-1 luc vector $(1 \mu \mathrm{g})$ or co-transfected with AP-1 luc vector plus scramble siRNA or ERK1/2 siRNA (50-200 nM) with Lipofectamine 2000. B-gal plasmid which contains galactosidase reporter gene was co-transfected with AP-1 luc vector to serve as control for transfection efficiency. Thirty-six hours after transfection, the cells were left untreated or treated with EGF $(50 \mathrm{ng} / \mathrm{ml})$ or IL-1 $\beta(20 \mathrm{ng} / \mathrm{ml})$ or both for $12 \mathrm{~h}$, luciferase assay (for AP-1) and enzyme assay (for B-gal) were then carried out according to the instructions of kit purchased from Promega Corp. (Madison, WI, USA).

Tissue samples. 105 cases of paraffin-embedded gastric adenocarcinoma (GA) tissue samples were obtained from Fuzhou General Hospital (Fuzhou, Fujian). The tissue samples were used with consent of the patients. This study was approved by the Ethics Committees of Fuzhou General Hospital.

Immunohistochemistry for phosphorylation of ERK1/2, EGF, $I L-1 \beta, E G F$ plus $I L-1 \beta, M M P-9$ and $c$-fos. For phosphorylation 
of ERK1/2 (p-ERK1/2) immunohistochemical detection (IHC) in the 105 cases of GA tissue samples, we used methods previously described for transgelin (20), using an anti-p-ERK1/2 antibody (1:100 dilution, Cell Signaling Co.) instead of an anti-transgelin antibody. The staining results were assessed on a four-tier scale based on Ju et al (21) and Ebert et al (22). To assess the levels of EGF, IL-1 $\beta$, EGF plus IL-1 $\beta$, MMP-9 and c-fos in GA tissues by IHC, we also used the method described above. Anti-MMP-9, and c-fos antibodies used for IHC were from Abcam Co.; anti-human IL-1 $\beta$ antibody was from Santa Cruz Biotechnology, Inc. (Santa Cruz, CA, USA).

Statistical analysis. Statistical significance of immunohistochemistry for p-ERK1/2 was analyzed by the Wilcoxon signed-ranks test, the $\chi^{2}$ test, the Fisher's exact test and t-test. Spearman' method was applied to evaluate the correlation in expression levels of P-ERK1/2 with IL-1 $\beta$, EGF, EGF plus IL-1 $\beta$, MMP-9 and c-fos in GA tissue samples. For other experiments, values are expressed as means $\pm \mathrm{SD}$, and independent-sample $\mathrm{T}$ test was performed to determine the difference among the groups. P-values $<0.05$ were considered statistically significant.

\section{Results}

EGF activates ERK1/2 and increases cell migration and invasion in GA cells. The ability of the representative growth factor EGF to activate ERK1/2 signaling was investigated in GA cells. As expected, expression of p-ERK1/2 was detected in both AGS and MKN-45 cells after stimulation with EGF for $30 \mathrm{~min}$, and EGF-induced expression of $\mathrm{p}$-ERK1/2 could be inhibited by the MEK/ERK pathway inhibitor U0126 (Fig. 1A and B).

To investigate whether EGF induced the migration and invasion of GA cells were mediated by ERK1/2 signaling activation, AGS and MKN-45 cells were stimulated with EGF in the presence or absence of U0126 or transfected with ERK1/2 siRNA. The results from Transwell assays demonstrated that EGF elevated the migration and invasion of AGS and MKN-45 cells. EGF-induced AGS and MKN-45 cell migration and invasion were significantly and dose-dependently attenuated by knockdown of ERK1/2 using 50-200 nM ERK1/2 siRNA (Fig. 1C-H). In a similar manner, U0126 significantly and dose-dependently inhibited EGF-induced cell migration and invasion (Fig. 1E-H). The results demonstrated that ERK1/2 played an essential role in growth factor-induced cell migration and invasion in GA cells, and demonstrated that the ability of ERK1/2 to stimulate GA cell migration and invasion were mediated by MEK1/2.

IL-1 $\beta$ activates ERK1/2 and increases cell migration and invasion in GA cells. Recently, increased attention has been paid to inflammatory microenvironment signaling, which has been demonstrated to play an important role in the progression of cancer, including cancer metastasis (23). The role of ERK1/2 in growth factor-induced metastasis is well characterized $(24,25)$; however, proinflammatory factors can also activate ERK1/2. IL-1 $\beta$ can activate ERK1/2 in several types of cells, including cancer cells $(26,27)$. To characterize whether or not IL-1 $\beta$ also participates in ERK1/2 mediated metastasis in GA, we treated AGS and MKN-45 cells with IL-1 $\beta$. As expected, IL-1 $\beta$ activated ERK1/2 in AGS and MKN-45 cells, as expression of p-ERK1/2 was detected after 30 min stimulation with IL-1 $\beta$ (Fig. 2A and B).

The effect of IL-1 $\beta$ on cell migration and invasion in AGS and MKN-45 cells were further examined. AGS and MKN-45 cells were treated with IL-1 $\beta$. IL-1 $\beta$ increased the cell migration and invasion of the cells. Transwell assays demonstrated that IL-1 $\beta$-induced cell migration and invasion were attenuated in a dose-dependent manner by siRNA-mediated knockdown of ERK1/2 (Fig. 2C-F). Additionally, the MEK/ ERK inhibitor U0126 significantly suppressed IL-1 $\beta$-induced AGS and MKN-45 cell migration and invasion (Fig. 2C-F). Taken together, these results demonstrated that IL-1 $\beta$-induced GA cell metastasis were mediated by the MEK/ERK signaling pathway, and also suggested that ERK1/2 signaling activation may play an important role in inflammatory factor-associated GA cell migration and invasion.

EGF and $I L-1 \beta$ additively increases ERK1/2-mediated-GA cell migration and invasion. Next, we investigated whether growth and inflammatory factors could additively affect GA cell migration and invasion. AGS and MKN-45 cells were stimulated with EGF plus IL-1 $\beta$. As shown in Fig. 3A and B, an approximately 2 -fold increase in p-ERK1/2 expression was observed in AGS (Fig. 3A) and MKN-45 (Fig. 3B) cells treated with EGF plus IL-1 $\beta$, compared cells treated with EGF or IL-1 $\beta$ alone. The ability of EGF plus IL-1 $\beta$ to activate ERK1/2 was almost completely blocked by ERK1/2 siRNA or U0126. Additionally, co-stimulation with EGF plus IL-1 $\beta$ additively elevated the migration and invasion of AGS and MKN-45 cells $>2$-fold, compared to cells treated with either EGF or IL-1 $\beta$ alone (Fig. 3C, E and F) (AGS cells) and (Fig. 3D, G and H) (MKN-45 cells). Therefore, growth and inflammatory factors additively promote ERK1/2-mediated GA cell migration and invasion.

EGF and $I L-1 \beta$ additively upregulates expression of MMP-9 in GA cells via activation of the ERK1/2 signaling pathway. Increased expression of MMP-9 is associated with cancer cell migration and invasion $(28,29)$. To investigate whether MMP-9 contributes to EGF and IL-1 $\beta$-induced ERK1/2-mediated metastasis, the activation of ERK1/2 and the expression of MMP-9 were examined by confocal microscopy with a p-ERK1/2 antibody (red fluorescently labeled), and MMP-9 antibody (green fluorescently labeled). As shown in Fig. 4, there was only a baseline activity of p-ERK1/2, and the expression of MMP-9 was very weak in AGS and MKN-45 cells, without EGF or IL-1 $\beta$ treatment. Whereas, after treated by EGF or IL-1 $\beta$ or both, the expression of p-ERK1/2 and MMP-9 were visibly increased (Fig. 4). The most obvious elevation of the p-ERK1/2 and MMP-9 had been observed in the cells treated with EGF plus IL-1 $\beta$ (Fig. 4). Pre-treatment of the cells with pathway inhibitor U0126 or transfection of the cells with ERK1/2 siRNA, significantly suppressed EGF plus IL-1 $\beta$ induced ERK1/2 activation and MMP-9 upregulation (Fig. 4).

EGF and $I L-1 \beta$ additively activate AP-1 in GA cells via the ERK1/2 signaling pathway. The transcription factor AP-1 regul- 
A

C
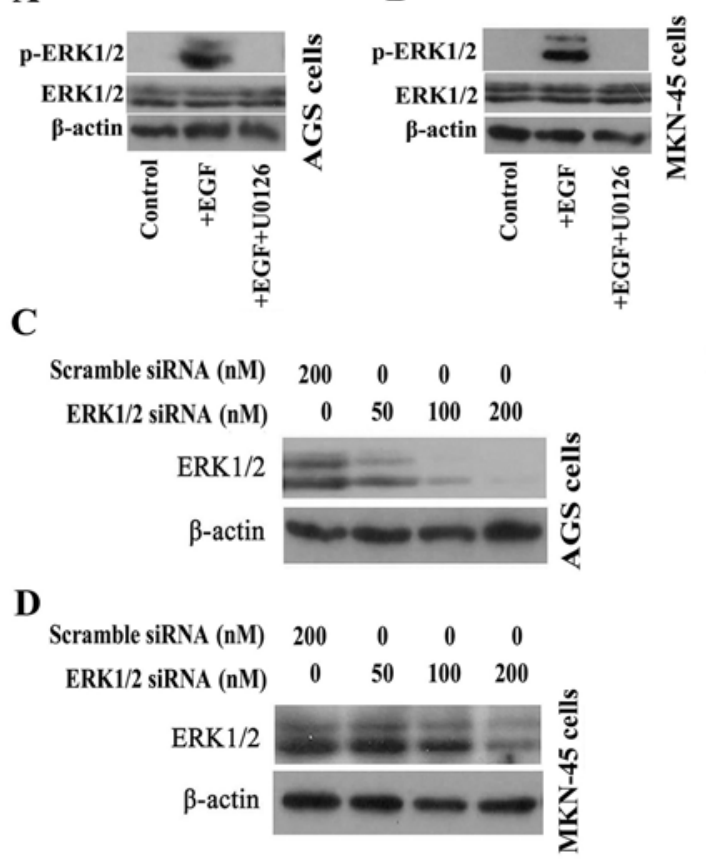

$\mathbf{E}$

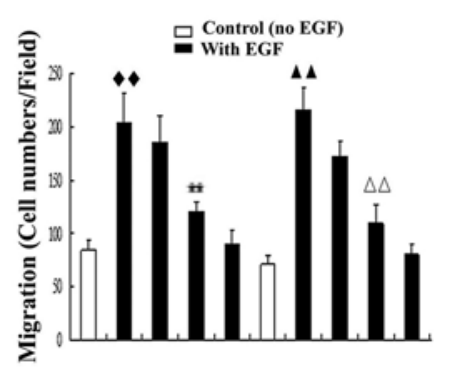

$\mathbf{F}$

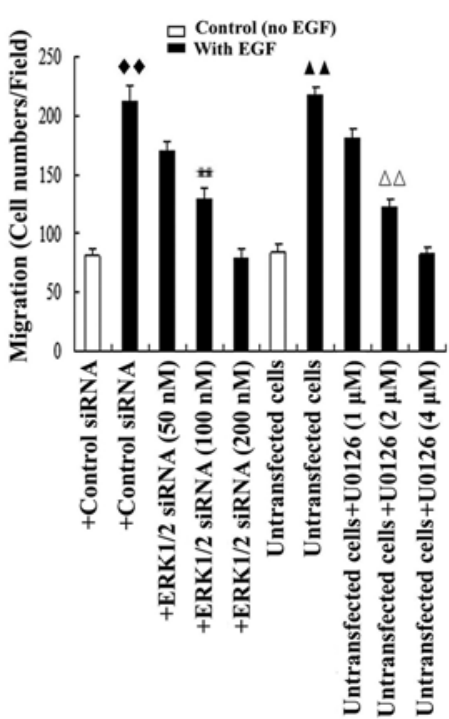

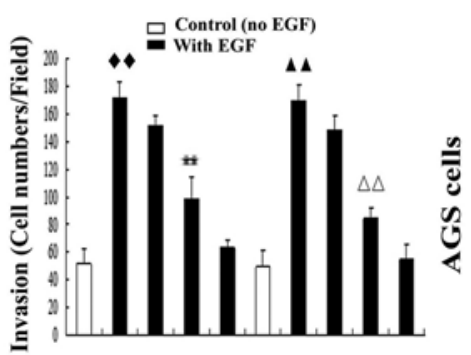

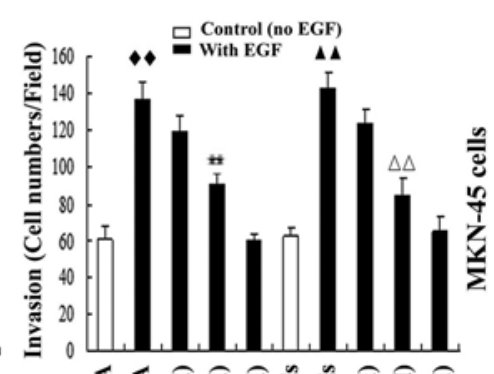

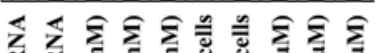

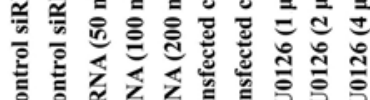

产

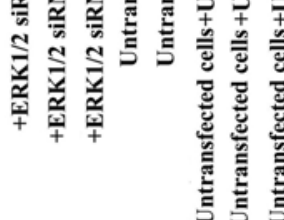

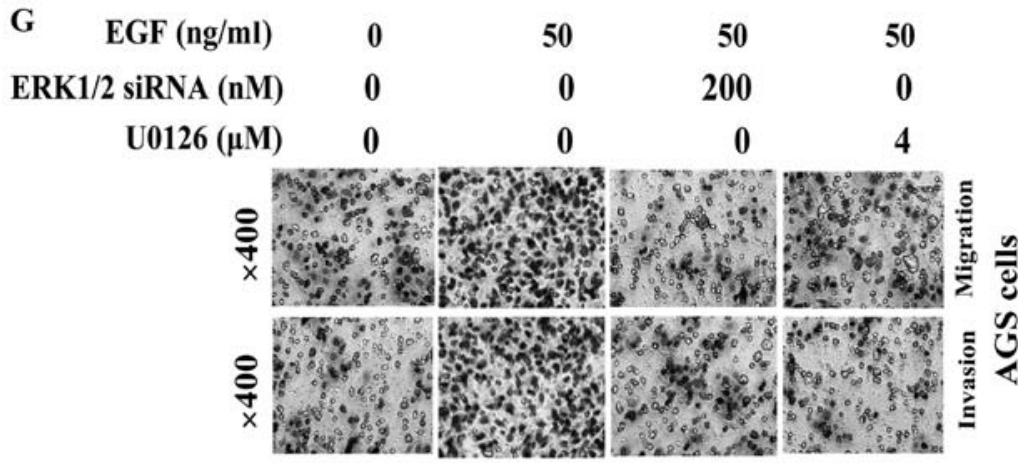

H

$\begin{array}{rrrrr}\text { EGF }(\mathrm{ng} / \mathrm{ml}) & 0 & 50 & 50 & 50 \\ \text { ERK1/2 siRNA }(\mathrm{nM}) & 0 & 0 & 200 & 0 \\ \text { U0126 }(\mu \mathrm{M}) & 0 & 0 & 0 & 4\end{array}$

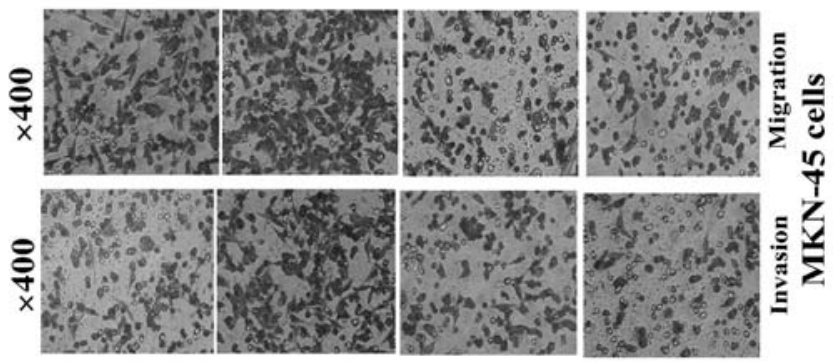

Figure 1. EGF increases cell migration and invasion in GA cells via activation of ERK1/2. (A) and (B) Western blot demonstrating that expression of p-ERK1/2 could be detected in AGS and MKN-45 cells stimulated with EGF; pre-treatment with U0126 significantly inhibited EGF-induced ERK1/2 activation. (C) and (D) Western blots confirming that transfection of ERK1/2 siRNA dose-dependently reduced the expression of ERK1/2 in both AGS and MKN-45 cells. (E) and (F) Transwell assays revealed that ERK1/2 siRNA (50-200 nM) dose-dependently reduced the ability of EGF to increase AGS and MKN-45 cell migration and invasion. EGF-induced cell migration and invasion were also dose-dependently inhibited by the MEK1/2 inhibitor U0126. ${ }^{* *} \mathrm{P}<0.05$ vs. siRNA negative control-transfected cells stimulated with EGF; ${ }^{\triangle} \mathrm{P}<0.05$ vs. untransfected cells stimulated with EGF. ${ }^{\bullet \bullet} \mathrm{P}<0.05$ vs. unstimulated siRNA negative control-transfected cells. ${ }^{\wedge} \mathrm{P}<0.05$ vs. unstimulated untransfected cells. Bars are the mean \pm SD: the number of cells per field of view (magnification $\mathrm{x} 200$ ) were counted in the migration and invasion assays. $(\mathrm{G})$ and $(\mathrm{H})$ Representative light microscopy images of AGS and MKN-45 cell migration and invasion in the Transwell assays. 

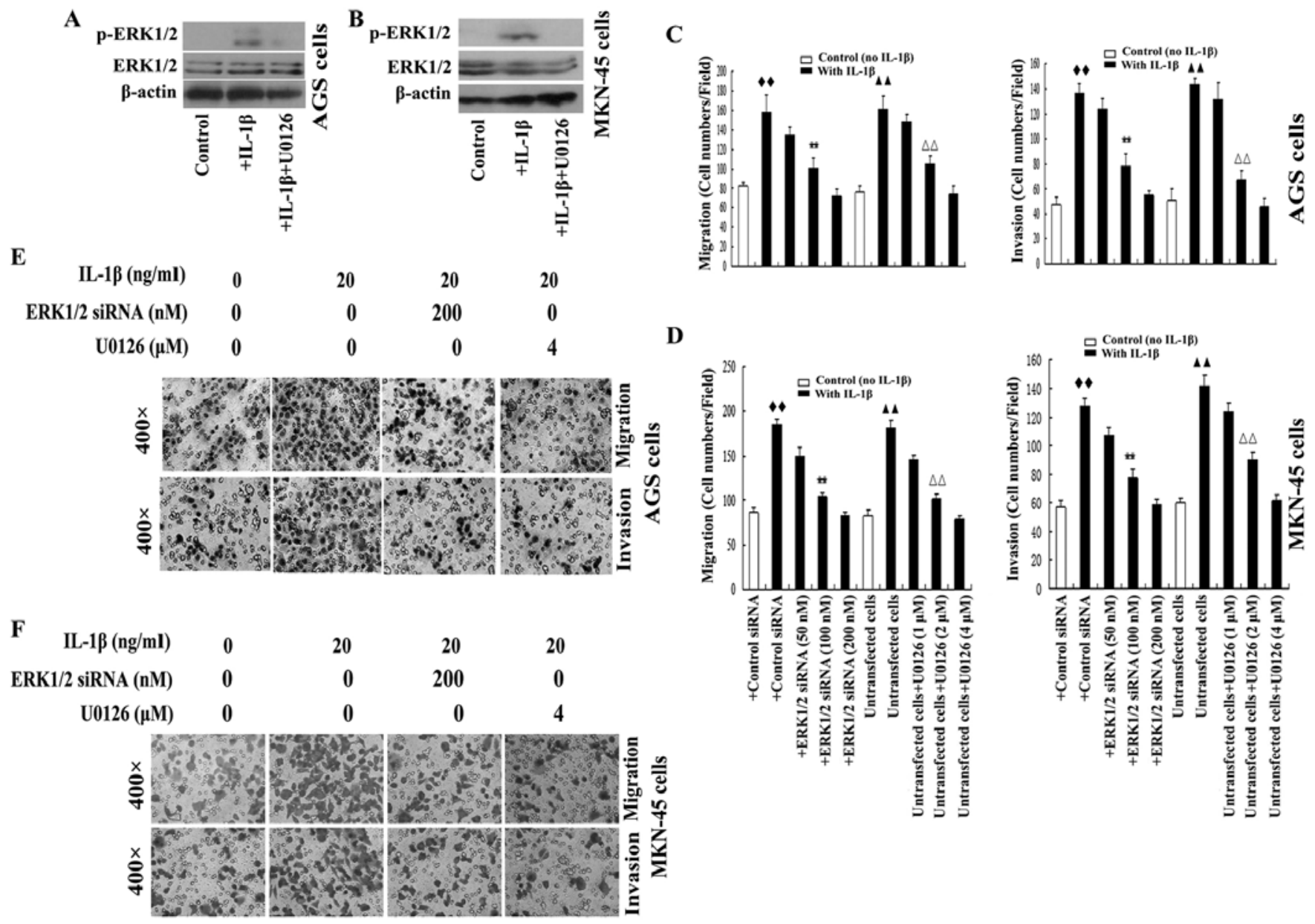

Figure 2. IL-1 $\beta$ increases cell migration and invasion in GA cells via activation of ERK1/2. (A) and (B) Western blot demonstrating that expression of p-ERK1/2 was detected in AGS and MKN-45 cells stimulated with IL-1 $\beta$ for 30 min; pre-treatment with the MEK1/2 inhibitor U0126 significantly inhibited IL-1 $\beta$-induced ERK1/2 activation. (C) and (D) Transwell migration assays revealed that $E R K 1 / 2$ siRNA (50-200 nM) dose-dependently reduced IL-1 $\beta$-induced AGS and MKN-45 cell migration and invasion; IL-1 $\beta$-induced cell migration and invasion were also dose-dependently inhibited by U0126. ** P<0.05 vs. siRNA negative control-transfected cells stimulated with IL-1 $\beta ;{ }^{\triangle} \mathrm{P}<0.05$ vs. untransfected cells stimulated with IL-1 $\beta .{ }^{\bullet \bullet} \mathrm{P}<0.05$ vs. unstimulated siRNA negative control-transfected cells. ${ }^{\wedge} \mathrm{P}<0.05$ vs. unstimulated untransfected cells. Bars are the mean \pm SD: the number of cells per field of view were counted in the migration and invasion assays. (E) and (F) Representative light microscopy images of AGS and MKN-45 cell migration and invasion in the Transwell assays.

ates the expression of MMP-9 (30) and ERK1/2 can regulate the activation of AP-1 $(31,32)$. Our data revealed that both EGF and IL-1 $\beta$ upregulated expression of MMP-9 in AGS (Fig. 4A) and MKN-45 (Fig. 4B) cells. In order to understand whether AP-1 was required for the EGF and IL-1 $\beta$-induced ERK1/2-mediated upregulation of MMP-9, transcriptional activation of AP-1 was examined in AGS and MKN-45 cells using an AP-1 luciferase reporter gene assay. As shown in Fig. 5, both EGF and IL-1 $\beta$ increased AP-1 reporter gene luciferase activity in AGS and MKN-45 cells; however, co-stimulation with EGF plus IL-1 $\beta$ additively increased AP- 1 activity $>2$-fold, compared to cells treated with either EGF or IL-1 $\beta$ alone (Fig. 5). Inhibition of ERK1/2 using ERK1/2 siRNA or U0126 dose-dependently reduced AP-1 reporter gene activity in cells treated with EGF or IL-1 $\beta$ alone or both EGF plus IL-1 $\beta$ (Fig. 5).

The clinicopathological features of gastric adenocarcinoma and relationship between expression of EGF plus $I L-1 \beta$ and phosphorylated ERK1/2, MMP-9, and AP-1. The expression of p-ERK1/2 with the clinicopathological features of GA was analyzed by IHC assay. As shown in Fig. 6A-D, elevated levels of p-ERK1/2 were detected in GA: p-ERK1/2 was expressed or overexpressed in 57 of the 105 GA tissues (54.29\%) compared to 19 of the $105(18.10 \%)$ non-neoplastic tissues $(\mathrm{P}=0.006)$. Positive $\mathrm{p}-\mathrm{ERK} 1 / 2$ expression was significantly associated with higher TNM stage, lymph node metastasis, and invasion beyond the serosa, but not with patient age, gender, tumor size, histological type or differentiation grade in GA (Table I). Expression or overexpression of p-ERK1/2 had no significant relationship with tumor size ( $\geq 3$ vs. $<3 \mathrm{~cm}$; $\mathrm{P}=0.306$ ), patient age ( $\geq 50$ vs. $<50$ years; $\mathrm{P}=0.793$ ) or gender (male vs. female; $\mathrm{P}=0.304)$. In addition, no significant difference in p-ERK expression was observed in tumors with different histological types $(\mathrm{P}=0.238)$ or differentiation grades ( $\mathrm{P}=0.428)$. Expression of P-ERK1/2 was detected in all four TNM stages; however, p-ERK1/2 was more frequent in stage $\mathrm{T} 4$ and $\mathrm{T} 3$ than $\mathrm{T} 2$ and $\mathrm{T} 1$. The expression of p-ERK1/2 was significantly different in patients with and without lymph node metastasis $(\mathrm{P}=0.028)$ and patients with and without cancer invasion beyond serosa $(\mathrm{P}=0.020)$. 

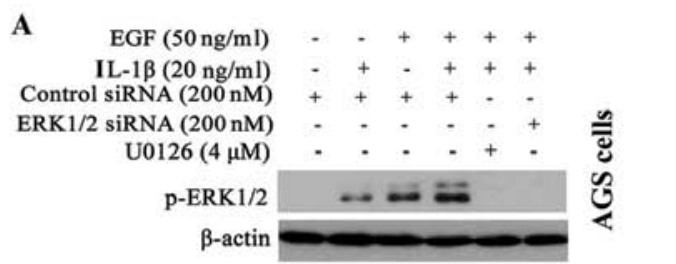

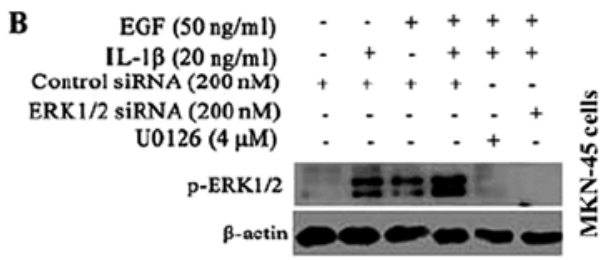

D

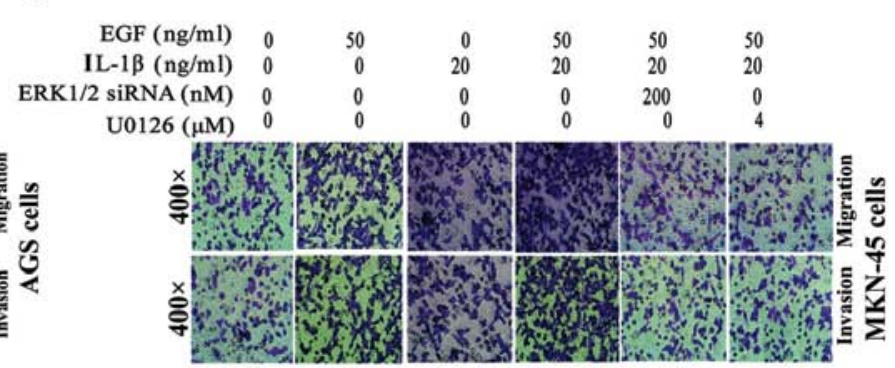

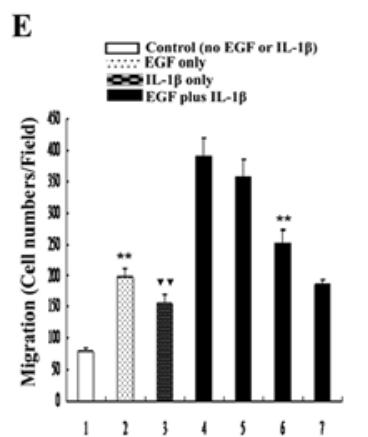
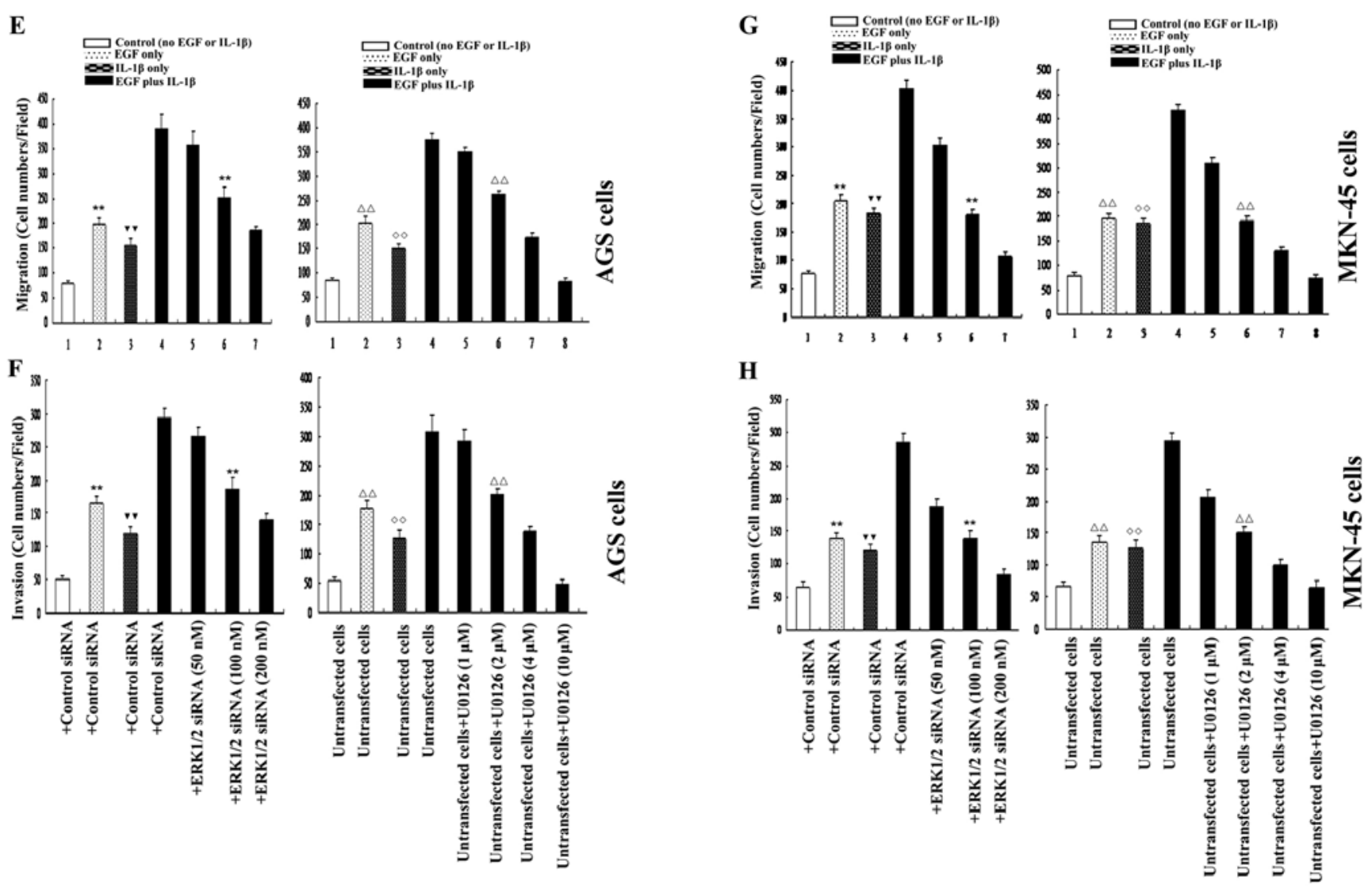

Figure 3. EGF and IL-1 $\beta$ additively activate ERK1/2 and increase GA cell migration and invasion. (A) and (B) Western blotting indicated that an approximately 2 -fold increase in ERK1/2 activation occurred in AGS and MKN-45 cells co-stimulated with EGF plus IL-1 $\beta$, compared to cells treated with EGF or IL-1 $\beta$ alone; ERK1/2 siRNA and the MEK1/2 inhibitor U0126 inhibited the activation of ERK1/2 by EGF plus IL-1 3 . (C) and (D) Representative light microscopy images of AGS and MKN-45 cell migration and invasion in the Transwell assays. (E) to (H) EGF plus IL-1 $\beta$ additively increased AGS and MKN-45 cell migration and invasion, leading to an approximately 2-fold increase, compared to cells treated with either EGF or IL-1 $\beta$ alone; ERK1/2 siRNA and U0126 inhibited EGF plus IL-1 $\beta$-induced AGS and MKN-45 cell migration and invasion. ${ }^{* *} \mathrm{P}<0.05$ vs. siRNA negative control-transfected cells stimulated with EGF plus IL-1 $\beta ;{ }^{\top} \mathrm{P}<0.05$ vs. unstimulated siRNA negative control-transfected cells. ${ }^{\triangle} \mathrm{P}<0.05$ vs. untransfected cells stimulated with EGF plus IL-1 $\beta$. ${ }^{\diamond} \mathrm{P}<0.05$ vs. unstimulated untransfected cells. Bars are the mean \pm SD: the number of cells per field of view were counted in the migration and invasion assays.

IHC assay was also used to detect the expression of p-ERK $1 / 2$ and EGF plus IL-1 $\beta$. The expression of p-ERK1/2 exhibited correlation with the levels of EGF alone ( $r=0.604$, $\mathrm{P}<0.01)$ or IL- $\beta$ alone $(\mathrm{r}=0.502, \mathrm{P}<0.05)$, but the good correlation was determined between the levels of $\mathrm{p}$-ERK1/2 with the levels of EGF plus IL-1 $\beta$ in GA tissues (Fig. 6E). Strong positive staining of $\mathrm{p}$-ERK1/2 was detected in the GA samples with higher levels of EGF plus IL-1 $\beta$; whereas, weak ERK1/2 expression was detected in lower levels of EGF plus IL-1 $\beta$ samples. When analyzed by Spearman's method, a correlation $(r=0.792, P<0.001)$ between the expression of $p-E R K 1 / 2$ and EGF plus IL-1 $\beta$ was obtained. 

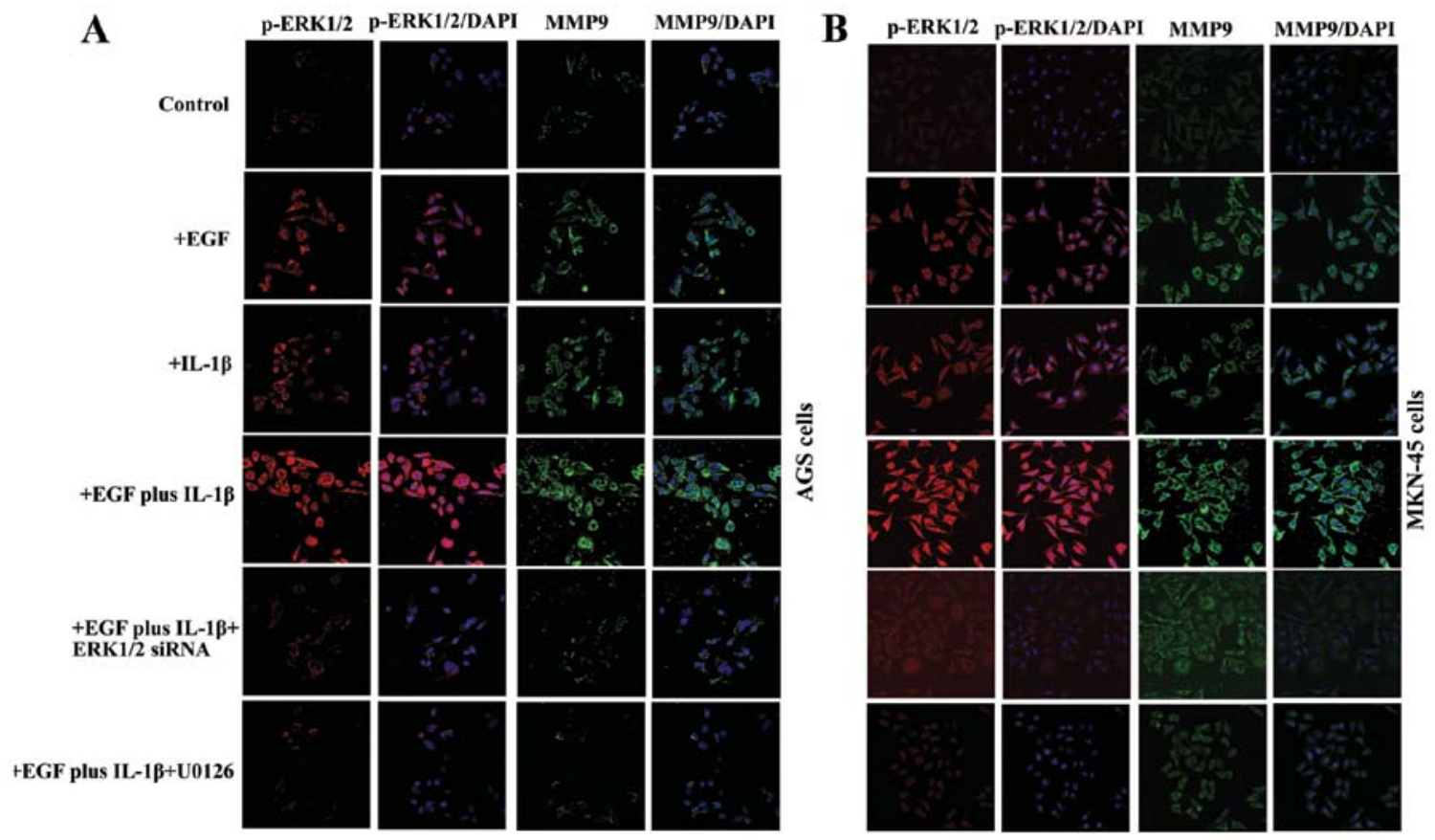

Figure 4. EGF and IL-1 $\beta$ additively upregulate $M M P-9$ in GA cells via the ERK1/2 pathway. (A) and (B) Confocal microscopy showed that the expression of p-ERK1/2 (red) and MMP-9 (green) was very weak in AGS and MKN-45 cells without EGF or IL-1 $\beta$ treatment. The expression of p-ERK1/2 was increased post-EGF stimulation and elevated MMP-9 expression was also detected in the same cells. IL-1 $\beta$ also caused ERK1/2 activation and elevated MMP-9 expression. EGF plus IL-1 $\beta$ treatment led to about 2-fold increased activation of ERK1/2 and the expression of MMP-9. ERK1/2 siRNA inhibited the activation of ERK1/2 and the expression of MMP-9. U0126 also inhibited the activation of ERK1/2 and the expression of MMP-9.
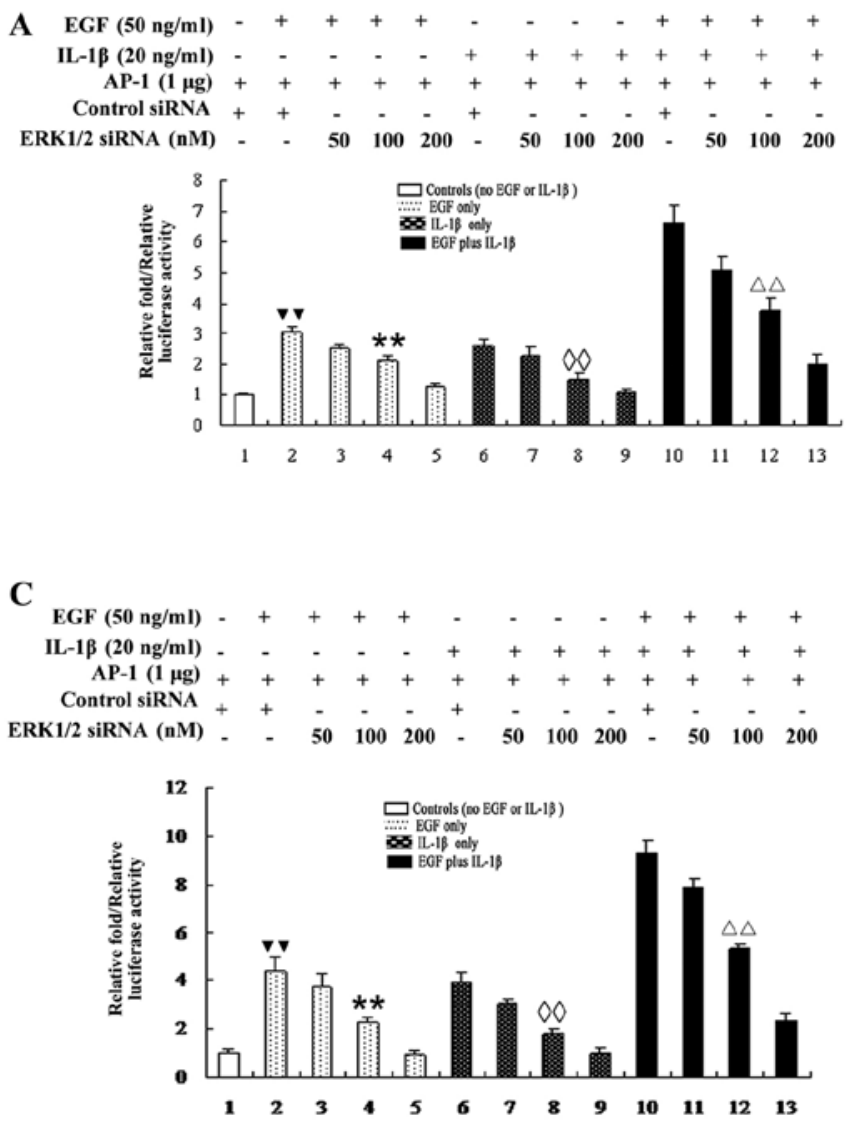

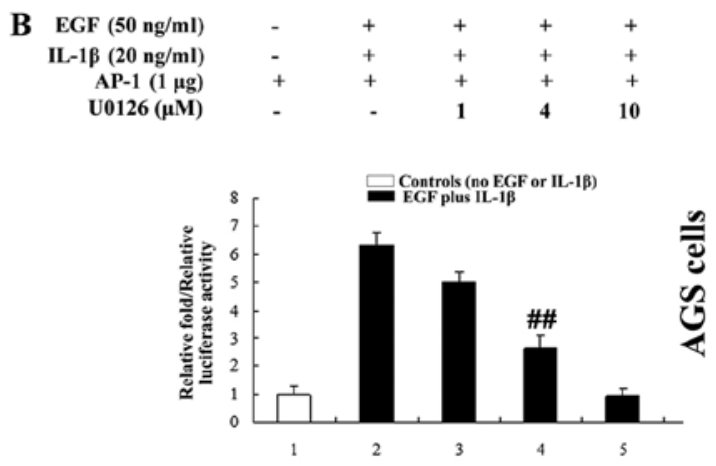

D
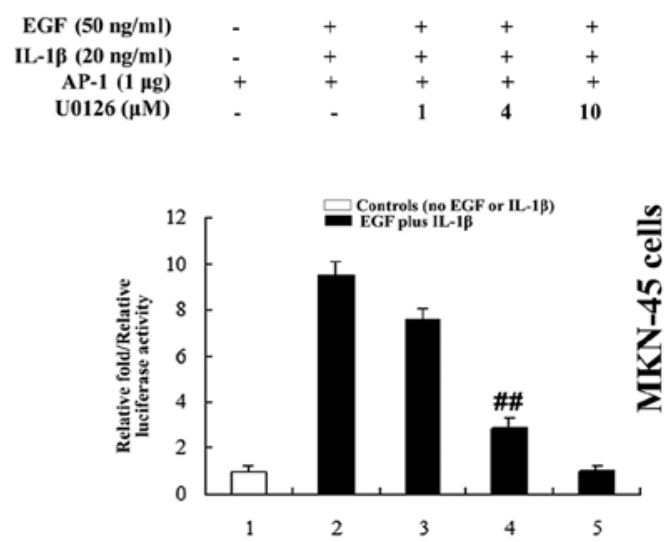

Figure 5. Additive activation of AP-1 by EGF plus IL- $1 \beta$ via ERK1/2 pathway. The additive activation of AP-1 by EGF plus IL-1 $\beta$ was inhibited by ERK1/2 siRNA. Both EGF and IL-1 $\beta$ increased AP-1 luciferase reporter gene activity in AGS (A and B) and MKN-45 cells (C and D); however, EGF plus IL-1 $\beta$ additively increased AP-1 luciferase activity; ERK1/2 siRNA and U0126 inhibited these effects in a dose-dependent manner. ${ }^{* *}$ or ${ }^{\triangleright} \mathrm{P}<0.05$ vs. control siRNA and AP-1 luc-transfected cells stimulated with EGF or IL-1 $\beta$ alone; ${ }^{*}$ and ${ }^{\triangle} \mathrm{P}<0.05$ vs. control siRNA and AP-1 luc-transfected cells stimulated with EGF plus IL-1 $\beta ;{ }^{\# \#} \mathrm{P}<0.05$ vs. only AP-1 luc-transfected cells stimulated with EGF plus IL-1 $\beta$. Relative luciferase activity was normalized to B-gal. 
The in vivo correlation of the expression of IL-1 $\beta$ plus EGF and p-ERK1/2 with MMP-9 and AP-1 (c-fos) in GA tissue samples was also detected by IHC. The expression of p-ERK1/2 correlated well with the levels of MMP-9 and c-fos in addition to EGF plus IL-1 $\beta$ (Fig. 6E). The results from statistical analyses showed that elevated p-ERK1/2 expression significantly correlated with the elevated expression of EGF plus IL-1 $\beta$, MMP-9 and c-fos in GA tissue samples ( $\mathrm{r}=0.792$, $\mathrm{P}<0.001 ; \mathrm{r}=0.713, \mathrm{P}<0.001 ; \mathrm{r}=0.704, \mathrm{P}<0.001$; respectively).

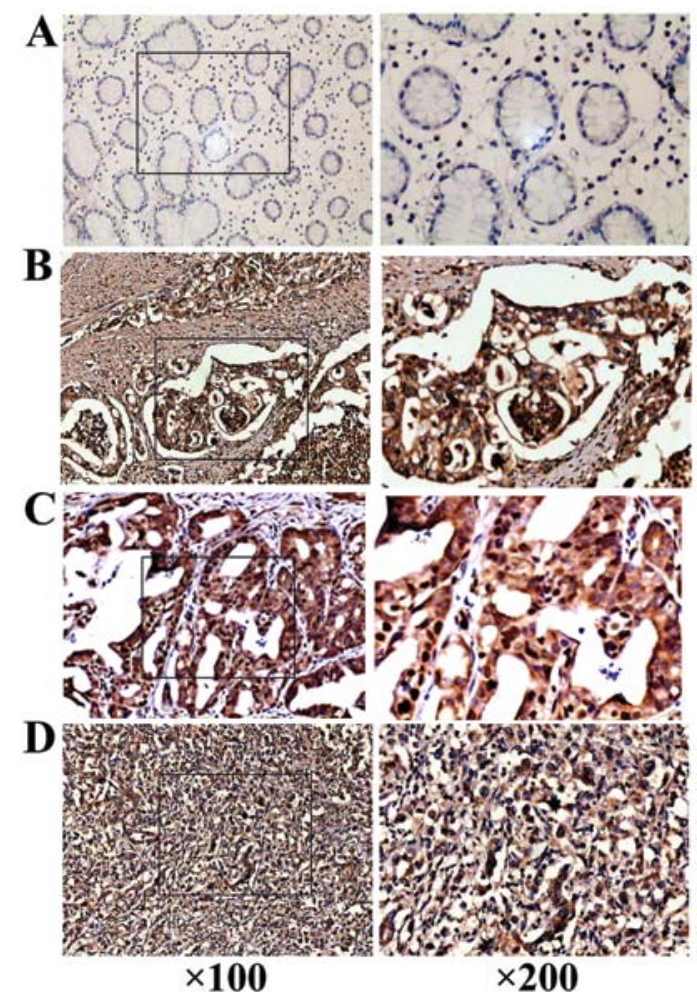

In vivo data further confirmed that EGF with IL-1 $\beta$ might additively activate ERK1/2, which in turn upregulated MMP-9 and c-fos expression in GA tissues.

\section{Discussion}

The EGF receptor is widely expressed in a variety of different cells, including cancer cells (33). Extensive research has been performed to characterize the role of EGF in cancer cell growth, metastasis and invasion (34); however, little is known about the effects of EGF on metastasis in GA. In accordance with previous research in other cancer cell lines $(35,36)$, we observed that EGF could increase AGS and MKN-45 cell migration, and invasion via a mechanism mediated by ERK1/2.

It is well established that gastric cancer carcinogenesis is closely related with inflammation. Cytokines, especially IL-1 $\beta$ plays crucial roles in gastric inflammatory reaction, and more and more evidence has suggested that inflammatory signaling also plays important roles in cancer progression (37). However, the effects of inflammatory factors on the signaling pathways which regulate metastasis are poorly characterized in GA cells, and the combined action of EGF and IL-1 $\beta$ in GA cells has not been detected previously. This study provides the first evidence that GA cell migration and invasion can by induced by IL-1 $\beta$ via activation of ERK1/2. More important, our data also demonstrated for the first time that EGF and IL- $1 \beta$ additively increased GA cell migration and invasion via activation of the ERK1/2 signaling pathway. It has been well documented that ERK1/2 plays a crucial role in the regulation of cancer cell metastasis $(9,10)$; however, the activation of ERK1/2 induced by growth factor plus inflammatory factor and the molecular mechanisms regulating ERK1/2 signaling in GA are still unclear. Here, we also demonstrated that ERK1/2 signaling can be activated by EGF plus IL- $1 \beta$ which was significantly and dose-dependently inhibited by the MEK1/2 inhibitor
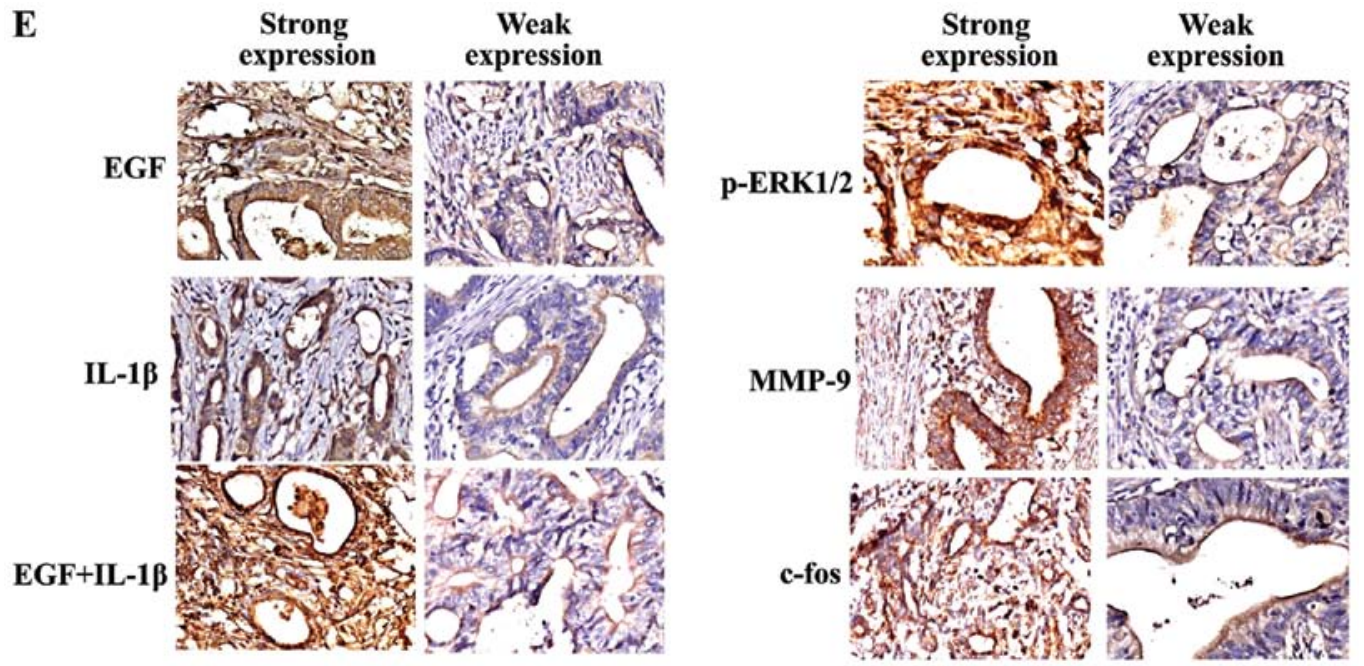

Figure 6. Representative results of IHC and correlation between the expression of EGF plus IL-1 $\beta$ and the expression of p-ERK1/2, MMP-9 and AP-1 in GA tissue. (A) Representative images demonstrating that non-neoplastic gastric tissues did not express or express very low levels of p-ERK1/2, whereas GA cells showed frequently overexpressed p-ERK1/2 (B-D). (B-D) exhibited different positive intensities of p-ERK1/2 in GA tissues detected by IHC. Images in the left panel: magnification at $x 100$, and on the right at $x 200$. (E) Stronger positive staining of pERK1/2 was detected in the GA tissues that showed stronger expression of EGF plus IL-1 $\beta$, MMP-9 and c-fos. Weaker expression of p-ERK1/2 was detected in the GA tissues that showed weaker expression of EGF plus IL-1 $\beta$, MMP-9 and c-fos. 
Table I. Association of p-ERK1/2 with clinicopathological features in gastric adenocarcinoma.

\begin{tabular}{|c|c|c|c|c|}
\hline Factor & $\mathrm{n}$ & $\begin{array}{c}\text { Negative/unchanged } \\
\mathrm{n}(\%)\end{array}$ & $\begin{array}{c}\text { Positive/overexpressing } \\
\mathrm{n}(\%)\end{array}$ & P-value \\
\hline \multicolumn{5}{|l|}{ Total } \\
\hline GA & 105 & $48(45.71)$ & 57 (54.29) & \multirow[t]{2}{*}{0.006} \\
\hline Non-neoplastic tissues & 105 & $86(81.90)$ & $19(18.10)$ & \\
\hline \multicolumn{5}{|l|}{ Age (years) } \\
\hline$<50$ & 25 & $12(48.00)$ & $13(52.00)$ & \multirow[t]{2}{*}{0.793} \\
\hline$\geq 50$ & 80 & $36(45.00)$ & $44(55.00)$ & \\
\hline \multicolumn{5}{|l|}{ Histological type } \\
\hline Intestinal & 51 & $26(50.98)$ & 25 (49.02) & \multirow[t]{3}{*}{0.238} \\
\hline Diffuse & 48 & $18(37.50)$ & $30(62.50)$ & \\
\hline Unknown $^{\mathrm{c}}$ & 6 & $4(66.67)$ & $2(33.33)$ & \\
\hline \multicolumn{5}{|l|}{ TNM stage } \\
\hline $\mathrm{T} 1$ & 20 & $16(80.00)$ & $4(20.00)$ & \multirow[t]{5}{*}{0.000} \\
\hline $\mathrm{T} 2$ & 32 & $17(53.13)$ & $15(46.88)$ & \\
\hline $\mathrm{T} 3$ & 30 & $8(26.67)$ & $22(73.33)$ & \\
\hline $\mathrm{T} 4$ & 15 & $2(13.33)$ & 13 (86.67) & \\
\hline Unknown $^{c}$ & 8 & $5(62.50)$ & $3(37.50)$ & \\
\hline \multicolumn{5}{|l|}{ Differentiation grade } \\
\hline $\operatorname{High}(\mathrm{H})$ & 21 & $13(61.90)$ & $8(38.10)$ & \multirow[t]{6}{*}{0.428} \\
\hline Moderate (M) & 28 & $12(42.86)$ & $16(57.14)$ & \\
\hline Poor (Pr) & 37 & $15(40.54)$ & $22(59.46)$ & \\
\hline Signet-ring (Sr) & 7 & $2(28.57)$ & $5(71.43)$ & \\
\hline Mucinous (Mu) & 4 & $1(25.00)$ & $3(75.00)$ & \\
\hline Unknown $^{c}$ & 8 & $5(62.50)$ & $3(37.50)$ & \\
\hline \multicolumn{5}{|l|}{ Gender } \\
\hline Male & 71 & $30(42.25)$ & $41(57.75)$ & \multirow[t]{2}{*}{0.304} \\
\hline Female & 34 & $18(52.94)$ & $16(47.06)$ & \\
\hline \multicolumn{5}{|l|}{ Tumor size $(\mathrm{cm})^{\mathrm{a}}$} \\
\hline$\geq 3$ & 69 & $29(42.03)$ & $40 \quad(57.97)$ & \multirow[t]{3}{*}{0.306} \\
\hline$<3$ & 35 & $19(54.29)$ & $16(45.71)$ & \\
\hline Unknown & 1 & $0 \quad(0.00)$ & $1(100.00)$ & \\
\hline \multicolumn{5}{|l|}{ Lymph node metastasis ${ }^{\mathrm{b}}$} \\
\hline Positive & 56 & $20(35.71)$ & $36(64.29)$ & \multirow[t]{2}{*}{0.028} \\
\hline Negative & 49 & $28(57.14)$ & $21(42.86)$ & \\
\hline \multicolumn{5}{|l|}{ Invasion beyond serosa } \\
\hline Positive & 34 & $10(29.41)$ & $24(70.59)$ & \multirow[t]{2}{*}{0.020} \\
\hline Negative & 71 & $38(53.52)$ & $33(46.48)$ & \\
\hline
\end{tabular}

${ }^{a}$ Tumor size was expressed as length $\mathrm{x}$ width; tumors with length or width $\geq 3 \mathrm{~cm}$ were classified as $\geq 3 \mathrm{~cm}$; tumors with both length and width $<3 \mathrm{~cm}$ were classified as $<3 \mathrm{~cm}$. ${ }^{\mathrm{b}}$ At least one positive lymph node. ${ }^{\mathrm{c}}$ Unknown samples were not included in the statistical analysis.

U0126 or ERK1/2 siRNA. Thus, the facts further confirmed the involvement of the ERK1/2 signaling pathway in the ability of EGF, IL- $1 \beta$ or EGF plus IL-1 $\beta$ to increase GA cell migration and invasion. Therefore, ERK1/2 signaling plays an important role in both growth factor and inflammatory factor-associated migration, and invasion in GA. 
To investigate the mechanism by which EGF plus IL-1 $\beta$ promoted the migration and invasion of GA cells, we investigated the expression of MMP-9 in GA cells. The breakdown of extracellular matrix (ECM) is an initial, critical step during cancer cell metastasis (38), and the involvement of MMPs in ECM degradation has been widely documented $(38,39)$. MMP-9 is closely associated with cancer invasion and metastasis $(30,40)$, as it degrades collagen in the basement membrane, allowing cancer cells to pass through the ECM and spread to the surrounding tissues. Our results revealed that EGF and IL-1 $\beta$ additively induced GA cell migration and invasion via activation of ERK1/2, which in turn elevated MMP-9 expression. Increased MMP-9 expression and activity have previously been identified as one of the major mechanisms by which ERK1/2 mediates cancer cell metastasis $(30,39)$. As a target of ERK1/2 signaling, the transcription factor AP-1 can regulate the expression of MMP-9 (41). EGF and IL-1 $\beta$ additively increased AP-1 reporter gene luciferase activity, and this effect could be inhibited by $E R K 1 / 2$ siRNA and U0126, confirming that the ability of EGF and/or IL-1 $\beta$ to activate AP-1 and upregulate MMP-9 were dependent on ERK1/2 signaling.

In order to verify the above results in vivo, the expression of p-ERK1/2, EGF plus IL-1 $\beta$, MMP-9 and AP-1 (c-fos) in GA tissues were analyzed. The data exhibited that the expression of p-ERK1/2 correlated well with the levels of EGF plus IL-1 $\beta$, MMP-9 and AP-1 in GA tissue, and the expression of p-ERK1/2 was detected in more than $50 \%$ of the human GA tissues tested, which was closely related to high TNM stage, tumor invasion beyond the serosa and lymph node metastasis. Therefore, both in vitro and in vivo data demonstrated that growth and inflammatory factors additively promote metastasis in GA, by increasing the migration and invasion of GA cells via activation of ERK1/2 signaling. Taken together, our data demonstrate that growth factor and inflammatory factor-induced activation of ERK1/2 may promote cancer cell metastasis in GA.

In conclusion, the results of this study demonstrate that overexpression of p-ERK $1 / 2$ is closely associated with metastasis in GA, which correlated well with EGF plus IL-1 $\beta$. EGF and IL-1 $\beta$ additively increased GA cell migration and invasion via activation of the ERK1/2 signaling pathway, leading to increased AP-1 transcriptional activity and upregulation of MMP-9. ERK1/2/EGF/IL-1 $\beta$ pathways may be closely associated with GA progression.

\section{Acknowledgements}

This study was supported by the National Natural Science Foundation of China (Grant No. 81372788), the Medical Scientific Research Key Foundation of Nanjing Command (No. 11Z032), the Army Clinical High and New Technology Major Project (No. 2010 gxjs026) and the Medical Scientific Research Foundation of Nanjing Command (No. 11MA107).

\section{References}

1. Jemal A, Bray F, Center MM, Ferlay J, Ward E and Forman D Global cancer statistics. CA Cancer J Clin 61: 69-90, 2011.

2. Ajani JA: Optimizing docetaxel chemotherapy in patients with cancer of the gastric and gastroesophageal junction evolution of the docetaxel, cisplatin, and 5-fluorouracil regimen. Cancer 113: 945-955, 2008
3. Yoo YA, Kang MH, Lee HJ, et al: Sonic hedgehog pathway promotes metastasis and lymphangiogenesis via activation of Akt, EMT, and MMP-9 pathway in gastric cancer. Cancer Res 71: 7061-7070, 2011.

4. Mebratu Y and Tesfaigzi Y: How ERK1/2 activation controls cell proliferation and cell death: Is subcellular localization the answer? Cell Cycle 8: 1168-1175, 2009.

5. Balmanno $\mathrm{K}$ and Cook SJ: Tumour cell survival signalling by the ERK1/2 pathway. Cell Death Differ 16: 368-377, 2009.

6. Abe MK, Saelzler MP, Espinosa R III, et al: ERK8, a new member of the mitogen-activated protein kinase family. J Biol Chem 277: 16733-16743, 2002.

7. Xu YM, Zhu F, Cho YY, et al: Extracellular signal-regulated kinase 8-mediated c-Jun phosphorylation increases tumorigenesis of human colon cancer. Cancer Res 70: 3218-3227, 2010.

8. Adams DG, Coffee RL Jr, Zhang H, et al: Positive regulation of Raf1-MEK1/2-ERK1/2 signaling by protein serine/threonine phosphatase 2A holoenzymes. J Biol Chem 280: 42644-42654, 2005.

9. Bai Y, Luo Y, Liu S, et al: PRL-1 protein promotes ERK1/2 and RhoA protein activation through a non-canonical interaction with the Src homology 3 domain of p115 Rho GTPase-activating protein. J Biol Chem 286: 42316-42324, 2011.

10. Guturi KK, Mandal T, Chatterjee A, et al: Mechanism of $\beta$-cateninmediated transcriptional regulation of epidermal growth factor receptor expression in glycogen synthase kinase $3 \beta$-inactivated prostate cancer cells. J Biol Chem 287: 18287-18296, 2012.

11. Takeuchi A, Eto M, Shiota M, Tatsugami K, et al: Sunitinib enhances antitumor effects against chemotherapy-resistant bladder cancer through suppression of ERK1/2 phosphorylation. Int J Oncol 40: 1691-1696, 2012.

12. Nakata W, Hayakawa Y, Nakagawa H, et al: Anti-tumor activity of the proteasome inhibitor bortezomib in gastric cancer. Int $\mathbf{J}$ Oncol 39: 1529-1536, 2011.

13. Leonardi GC, Candido S, Cervello M, et al: The tumor microenvironment in hepatocellular carcinoma. Int J Oncol 40: 1733-1747, 2012.

14. Soria G, Ofri-Shahak M, Haas I, et al: Inflammatory mediators in breast cancer: coordinated expression of TNF $\alpha$ and IL- $1 \beta$ with CCL2 and CCL5 and effects on epithelial-to-mesenchymal transition. BMC Cancer 11: 130, 2011.

15. Yang HT, Cohen P and Rousseau S: IL-1beta-stimulated activation of ERK1/2 and p38 alpha MAPK mediates the transcriptional up-regulation of IL-6, IL-8 and GRO-alpha in HeLa cells. Cell Signal 20: 375-380, 2008.

16. Tsai CY, Lee TS, Kou YR, et al: Glucosamine inhibits IL-1betamediated IL-8 production in prostate cancer cells by MAPK attenuation. J Cell Biochem 108: 489-498, 2009.

17. Huang Q, Yang J, Lin Y, et al: Differential regulation of interleukin 1 receptor and Toll-like receptor signaling by MEKK3. Nat Imm 5: 98-103, 2004.

18. Huang Q, Lan F, Zheng Z, et al: Akt2 suppresses GAPDH mediated-apoptosis in ovarian cancer cells via phosphorylating gapdh at threonine 237 and decreasing its nuclear translocation. J Biol Chem 286: 42211-42220, 2011.

19. Sumida T, Itahana Y, Hamakawa H, et al: Reduction of human metastatic breast cancer cell aggressiveness on introduction of either form A or B of the progesterone receptor and then treatment with progestins. Cancer Res 64: 7886-7892, 2004.

20. Huang QJ, Huang QL, Chen WN, et al: Identification of transgelin as a potential novel biomarker for gastric adenocarcinoma based on proteomics technology. J Cancer Res Clin Oncol 134: 1219-1227, 2008.

21. Ebert M, Yokoyama M, Kobrin MS, et al: Induction and expression of amphiregulin in human pancreatic cancer. Cancer Res 54: 3959-3962, 1994

22. Ju XZ, Yang JM, Zhou XY, et al: Emmprin expression as a prognostic factor in radiotherapy. Clin Cancer Res 12: 494-501, 2008.

23. Chen MF, Lu MS, Chen PT, et al: Role of interleukin 1 beta in esophageal squamous cell carcinoma. J Mol Med (Berl) 90: 89-100, 2012.

24. Park S, Jung HH, Park YH, et al: ERK/MAPK pathways play critical roles in EGFR ligands-induced MMP1 expression. Biochem Biophys Res Commun 407: 680-686, 2011.

25. Komurov K, Padron D, Cheng T, et al: Comprehensive mapping of the human kinome to epidermal growth factor receptor signal. J Biol Chem 285: 21134-21142, 2010.

26. Angst E, Reber HA, Hines OJ, et al: Mononuclear cell-derived interleukin-1 beta confers chemoresistance in pancreatic cancer cells by upregulation of cyclooxygenase-2. Surgery 144: 57-65, 2008. 
27. Arakawa T, Hayashi $\mathrm{H}$, Itoh $\mathrm{S}$, et al: IL-1-induced ERK1/2 activation up-regulates $\mathrm{p} 21$ (Waf1/Cip1) protein by inhibition of degradation via ubiquitin-independent pathway in human melanoma cells A375. Biochem Biophys Res Commun 392: 369-372, 2010.

28. Deryugina EI and Quigley JP: Matrix metalloproteinases and tumor metastasis. Cancer Metastasis Rev 25: 9-34, 2006.

29. Yadav VR, Prasad S, Gupta SC, et al: 3-Formylchromone interacts with cysteine 38 in p65 protein and with cysteine 179 in $\mathrm{I} \alpha \mathrm{B} \alpha$ kinase, leading to down-regulation of nuclear factor- $x \mathrm{~B}$ $(\mathrm{NF}-x \mathrm{~B})$-regulated gene products and sensitization of tumor cells. J Biol Chem 287: 245-256, 2012.

30. Han H, Du B, Pan X, et al: CADPE inhibits PMA-stimulated gastric carcinoma cell invasion and matrix metalloproteinase-9 expression by FAK/MEK/ERK mediated AP-1 activation. Mol Cancer Res 8: 1477-1488, 2010.

31. Babykutty S, Suboj P, Srinivas $\mathrm{P}$, et al: Insidious role of nitric oxide in migration/invasion of colon cancer cells by upregulating MMP-2/9 via activation of cGMP-PKG-ERK signaling pathways. Clin Exp Metastasis 29: 471-492, 2012.

32. Fujisawa T, Joshi BH and Puri RK: IL-13 regulates cancer invasion and metastasis through IL-13R $\alpha 2$ via ERK/AP-1 pathway in mouse model of human ovarian cancer. Int J Cancer 131: 344-356, 2012.

33. Han W and Lo HW: Landscape of EGFR signaling network in human cancers: biology and therapeutic response in relation to receptor subcellular locations. Cancer Lett 318: 124-134, 2012.
34. Yotsumoto F, Sanui A, Fukami T, et al: Efficacy of ligand-based targeting for the EGF system in cancer. Anticancer Res 29: 4879-4885, 2009.

35. Schäfer B, Gschwind A and Ullrich A: Multiple G-proteincoupled receptor signals converge on the epidermal growth factor receptor to promote migration and invasion. Oncogene 23: 991-999, 2004.

36. Cragg MS, Kuroda J, Puthalakath $\mathrm{H}$, et al: Gefitinib-induced killing of NSCLC cell lines expressing mutant EGFR requires BIM and can be enhanced by BH3 mimetics. Plos Med 4: 1681-1689, 2007.

37. Kaler P, Godasi BN, Augenlicht L, et al: The NF-kappaB/ AKT-dependent induction of Wnt signaling in colon cancer cells by macrophages and IL-1beta. Cancer Microenviron 2: 69-80, 2009.

38. Rucci N, Sanità P and Angelucci A: Roles of metalloproteases in metastatic niche. Curr Mol Med 11: 609-622, 2011.

39. Luo Y, Liang F and Zhang ZY: PRL1 promotes cell migration and invasion by increasing MMP2 and MMP9 expression through Src and ERK1/2 pathways. Biochemistry 48: 1838-1846, 2009.

40. Deryugina EI and Quigley JP: Matrix metalloproteinases and tumor metastasis. Cancer Metastasis Rev 25: 9-34, 2006.

41. Huang C, Ma WY and Dong Z: The extracellular-signalregulated protein kinases (Erks) are required for UV-induced AP-1 activation in JB6 cells. Oncogene 18: 2828-2835, 1999. 